\title{
Analisis Sosial Budaya yang Mempengaruhi Pelaksanaan Program Wajib Belajar Pendidikan Dasar Sembilan Tahun
}

\author{
Fitri Nur Millah', Yadi Ruyadi², Encep Syarief Nurdin ${ }^{3}$ \\ ${ }^{1}$ MAN Daruul Abror \\ ${ }^{2}$ Dosen Program Studi Pendidikan Sosiologi \\ ${ }^{3}$ Dosen Program Studi Pendidikan Sosiologi
}

\begin{abstract}
ABSTRAK
Penelitian ini bertujuan untuk mendeskripsikan dan menganalisis faktor sosial budaya yang melatarbelakangi pelaksanaaan wajar dikdas 9 tahun di kecamatan Cibeber. Penelitian menggunakan pendekatan kualitatif, dengan metode studi kasus. Teknik pengumpulan data dilakukan melalui wawancara, observasi, dan studi dokumentasi. Hasil penelitian adalah bahwa pelaksanaan wajib belajar pendidikan dasar sembilan tahun masih belum efektif. Terdapat faktor sosial dan budaya yang memberikan pengaruh terhadap partisipasi pendidikan masyarakat khususnya dalam wajib belajar 9 tahun.

Kata kunci : Sosial, Budaya, Wajib Belajar, Pendidikan Dasar Sembilan Tahun

\section{PENDAHULUAN}

Pendidikan sebagai salah satu pilar penting masa depan menjadikan hal tersebut wajib didapatkan oleh setiap individu. Mengingat sangat pentingnya pendidikan dalam rangka mencerdaskan anak bangsa pemerintah telah menyelenggarakan berbagai program yang bertujuan agar seluruh warga dapat memperoleh pendidikan.

Pendidikan wajib belajar 9 tahun merupakan suatu program pemerintah yang bertujuan untuk memeratakan pendidikan di

Indonesia serta sebagai salah satu upaya untuk menekan angka anak putus sekolah.

Kabupaten Cianjur sebagai salah satu kabupaten di Jawa Barat berdasarkan angka Indeks Pembangunan Manusia (IPM) menurut Pusat Data dan Analisis Pembangunan (Pusdalisbang) Jawa Barat masih berada di tingkat tiga terbawah diatas Kabupaten Cirebon dan Kabupaten Indramayu. IPM Kabupaten Cianjur pada tahun 2011 sebesar 69,55. Angka IPM tersebut dipengaruhi pula oleh berbagai faktor yang diantaranya adalah pendidikan.
\end{abstract}


Kecamatan Cibeber, Kabupaten Cianjur dalam melaksanaan wajib belajar 9 tahun dapat dikategorikan belum efektif karena adanya beberapa titik desa di kecamatan tersebut yang masyarakatnya tidak menyekolahkan anak-anaknya ke jenjang SMP.

Pelaksanaan wajib belajar pendidikan dasar sembilan tahun di Kecamatan Cibeber ini turut dipengaruhi oleh kondisi sosial dan faktor budaya yang ada serta melekat dalam diri masyarakat itu sendiri. Faktor budaya yang melekat di dalam masyarakat sebagai salah satu faktor yang akan memberikan kontribusi pula terhadap partisipasi pendidikan masyarakatnya. Unsur budaya yang sudah melekat dalam diri masyarakat tentunya akan terus hidup dan sulit untuk merubah sehingga unsur-unsur budaya tersebut dapat menghambat untuk meningkatkan partisipasi pendidikan masyarakat.

\section{HASIL PENELITIAN}

Pemerataan sekolah di setiap kecamatan disesuaikan dengan luas wilayah serta jumlah penduduknya dan terkadang pula pemerataan ini terkendala oleh akses ke tempat-tempat yang memang sulit dilalui oleh kendaraan dan jauh dari perkotaan. Perluasan kesempatan untuk memperoleh pendidikan bagi warga memang masih terkendala oleh belum meratanya jumlah sekolah yang ada di berbagai wilayah khususnya wilayah pelosok.

Pelaksanaan wajib belajar pendidikan dasar sembilan tahun pada jalur formal yang dilaksanakan di sekolah masih terkendala oleh adanya Ujian Nasional pada tingkat SD sehingga pendidikan wajib belajar 9 tahun masih terpisahkan. Sehingga siswa SD tidak dapat langsung masuk SMP namun harus melalui UN terlebih dahulu.

Pelaksanaan wajib belajar juga dapat dilakukan pada jalur nonformal yaitu melalui program Paket $A$ yang setara dengan SD dan Paket $B$ yang setara dengan SMP. Program paket A dan B ini berada di bawah tanggung jawab bidang Pendidikan Luar Sekolah (PLS) sehingga tenaga pendidiknya pun dari pihak PLS namun juga terdapat guru SD dan SMP yang turut menjadi pengajar di program Paket $A$ dan B. Program Paket A dan B ini dilaksanakan di Pusat Kegiatan Belajar Masyarakat (PKBM) yang ada di kampung Pasirsantri.

Wajib belajar pendidikan dasar 9 tahun dijamin oleh pemerintah mulai dari tenaga pendidik, sarana prasarana dan biaya operasional. Tenaga pendidik yang ada di Kecamatan Cibeber ini secara kuantitas telah 
memenuhi namun penyebarannya masih belum merata dimana masih terpusat di wilayah pusat kecamatan. Sedangkan di wilayah perkampungan dan pelosok masih banyak sekolah yang kekurangan guru sehingga memaksa untuk memberdayakan tenaga sukwan yang masih lulusan SMA dan SMK menjadi tenaga pengajar.

Sarana dan prasarana wajib belajar yang berkaitan dengan fasilitas bangunan sekolah juga masih belum merata, di wilayahwilayah pelosok masih banyak yang kekurangan sekolah dan juga ruang kelas. Selain dari kekurangan sekolah dan ruang kelas, beberapa masalah yang berkaitan dengan sarana adalah kurangnya alat peraga pendukung pembelajaran di beberapa sekolah sehingga pembelajaran kurang maksimal.

Aulia (2012, hlm. 213) menjelaskan bahwa "sarana prasarana di sekolah negeri pada umumnya bisa menggunakan BOPDA terkait perawatan dan biaya perbaikan". Biaya Operasional Pendidikan Daerah (BOPDA) sendiri bisa dipergunakan untuk pembangunan gedung sekolah dan ruang kelas baru.

Wajib belajar 9 tahun ditandai dengan dijaminnya biaya operasional pendidikan yang diantaranya membebaskan orangtua siswa dari biaya sekolah melalui Biaya Operasional Sekolah.

Masyarakat sepatutnya melakukan pengawasan terhadap pelaksanaan program wajib belajar pendidikan dasar 9 tahun ini sehingga dapat berjalan dengan maksimal. Bentuk pengawasannya dari pihak kecamatan belum sampai pada pengawasan pelaksanaan baru kepada tahap himbauan karena untuk pengawasan pelaksanaannya dilakukan oleh instansi lain. Sedangkan menurut salah satu tokoh masyarakat yang juga selaku pemimpin yayasan sendiri pengawasan dilakukan mencakup pelaksanaan pembelajaran yang ada di sekolah ini saja, karena berkaitan dengan kewenangan yang dimiliki tidak bisa melakukan pengawasan kepada sekolah lain. Bentuk pengawasannya tentu adalah dengan melihat perkembangan animo masyarakat dalam menyekolahkan anaknya, jika hal tersebut sudah tinggi maka masyarakat sudah memiliki kesadaran dalam pendidikan dan mendukung pelaksanaan wajar dikdas 9 tahun tersebut.

Salah satu langkah untuk mengawasi dan berperan aktif dalam mendukung wajar dikdas 9 tahun adalah dengan menjalin 
komunikasi dengan sekolah maupun guru.

Selain itu juga ada tim percepatan penuntasan wajib belajar yang terdiri dari tim kecamatan, desa, RW dan RT. Pengisi tim percepatan wajar dikdas di tingkat kecamatan ini biasanya gabungan dan camat sebagai pembina, biasanya digabungkan dengan rapat koordinasi kecamatan dengan desa-desa untuk setiap memberikan program himbauan wajar dikdas.

Upaya tokoh masyarakat dalam mendukung pelaksanaan wajar dikdas 9 tahun dan khususnya meningkatkan partisipasi pendidikan warga adalah dengan mengadakan perlombaan-perlombaan yang dilaksanakan di tingkat daerah dengan tujuan meningkatkan motivasi anak dalam meraih prestasi yang lebih baik.

Komunikasi yang terjalin antara orangtua dengan anak berkaitan dengan pembelajaran bisa dikatakan ada hanya ketika didesak oleh kebutuhan. Misalnya anak akan menyampaikan kepada orangtua ketika ada tugas sekolah yang susah, di luar itu orangtua cenderung acuh tak acuh terhadap perkembangan anak. Hal ini karena orangtua tidak menanyakan perkembangan secara berkelanjutan dan terus menerus. Namun ketika memang anak meminta bantuan maka orangtua berusaha membantu sebisa mereka.

Selain itu komunikasi antara orangtua dengan guru dilakukan secara intens ketika terdapat anak yang bermasalah. Pihak sekolah menjalin komunikasi yang baik dengan masyarakat dan juga orangtua siswa, seperti yang disampaikan sebelumnya bahwa orangtua siswa dan masyarakat banyak memberikan masukan kepada pihak sekolah sehingga sekolah banyak melakukan perbaikan.

Latar belakang pendidikan masyarakat kecamatan Cibeber mayoritasnya adalah lulusan SD dan SMP. Walaupun memang masih banyak diantaranya juga lulusan SMA dan yang telah bergelar diploma maupun sarjana. Namun di desa Girimulya sendiri warga yang telah bergelar diploma dan sarjana masih hanya segelintir orang saja, dan kebanyakan diantaranya adalah guru.

Dikarenakan latarbelakang pendidikan masyarakat kecamatan Cibeber sendiri mayoritasnya adalah lulusan SD dan SMP mengakibatkan kesulitan untuk mendapatkan pekerjaan yang layak dalam meningkatkan perekonomian keluarganya. Dimana mayoritas mata pencaharian dari 
masyarakat kecamatan Cibeber adalah dalam bidang pertanian seperti buruh tani dan petani namun selain itu ada juga yang bekerja di bidang industri seperti perdagangan. Selain itu juga disebutkan bahwa selain di bidang pertanian dan perdagangan, masyarakat juga ada yang bekerja menjadi buruh bangunan dan buruh angkut padi atau hasil panen.

Anak perempuan di desa Girimulya yang tidak melanjutkan sekolah ada yang langsung dinikahkan namun ada pula yang setelah beberapa waktu baru dinikahkan. Namun memang kebanyakan orangtua yang memiliki anak perempuan dan tidak sekolah akan menikahkan anaknya secepat mungkin. Hal ini karena jika anak perempuan yang tidak sekolah dibiarkan lama-lama akan terbawa pergaulan dan khawatir akan menjadi nakal. Maka dari itu orang tua memilih untuk menikahkan anaknya.

Bagi anak yang tidak melanjutkan sekolah maka mereka memilih untuk bekerja, karena ia tidak memiliki semangat melanjutkan pendidikan karena sudah terlena dengan bekerja dan punya uang. Pihak kecamatan mengantisipasi hal ini dengan mengarahkan untuk meningkatkan keterampilan untuk kepentingan yang bersangkutan agar pekerjaannya tidak monoton dan dapat meningkat.

Masyarakat kecamatan Cibeber masih beranggapan bahwa pendidikan di pesantren yang lebih utama karena lebih fokus pada pendidikan agama. Orangtua banyak yang menginginkan anaknya untuk melanjutkan pendidikan ke pesantren dibandingkan dengan keinginan anaknya sendiri. Selain itu karena daripada anaknya menganggur lebih baik menimba ilmu di pesantren.

Untuk

meningkatkan

partisipasi pendidikan masyarakat terdapat organisasi yang menangani masalah pendidikan selain dinas pendidikan ada juga PGRI yaitu forum bagi para guru sedangkan dinas Pendidikan sendiri memiliki mitra pendidikan yang ikut mengawasi berbagai macam kegiatan pendidikan yakni Dewan Pendidikan.

Dinas

pendidikan membentuk tim percepatan wajar dikdas yang ada di tingkat kecamatan, desa, RW dan RT pada tahun 2006. Orang-orang yang mengisi tim wajar dikdas ini adalah orang-orang yang menjabat sebagai camat, kepala desa, ketua RW dan ketua RT. Namun sekarang tim wajar dikdas ini kurang berjalan, karena 
orang yang mengisi jabatannya berganti.

\section{WAJIB BELAJAR 9 TAHUN}

Wajib belajar 9 tahun sendiri merupakan program yang bersifat persuasif dan tidak memaksa.

Pelaksanaan wajib belajar pendidikan dasar 9 tahun bertujuan untuk memberikan pelayanan pendidikan dan mengupayakan perluasan serta pemerataan kesempatan memperoleh pendidikan yang bermutu bagi setiap warga. Perluasan dan pemerataan pendidikan yang dilaksanakan melalui program wajib belajar 9 tahun ini berupaya agar seluruh warga yang berada di wilayah perkotaan maupun yang berada di wilayah-wilayah pelosok mampu untuk bersekolah.

Penyelenggaraan wajib
belajar dijelaskan dalam
Peraturan Pemerintah RI nomor
47 Pasal 3, yaitu wajib belajar dapat diselenggarkan pada jalur pendidikan formal, pendidikan nonformal, dan pendidikan informal. Penyelenggaraan wajib belajar pada jalur formal sendiri dilaksanakan pada jenjang pendidikan dasar yang meliputi SD, MI, SMP, MTs dan bentuk lainnya yang sederajat.

Wajib belajar pendidikan dasar 9 tahun ini masih terpisahkan dengan adanya Ujian Nasional SD dan juga sistem penerimaan SMP yang memberatkan siswa. Ujian Nasional SD yang harus dijalankan memisahkan konsep wajib belajar 9 tahun, karena akan memberikan jembatan pemisah bagi anak untuk melanjutkan sekolah ke tingkat SMP. Keberhasilan wajib belajar pendidikan dasar 9 tahun ini terlihat dari angkat partisipasi pendidikan masyarakat yakni melalui Angka Partisipasi Kasar (APK) dan Angka Partisipasi Murni (APM). Adapun APK kecamatan Cibeber untuk tingkat SD adalah 109,29 dan APM-nya 97,45. Sedangkan untuk APK dan APM tingkat SMP yakni sebesar 66,86 untuk APK dan 58,83 untuk SMP. Angka Partisipasi Kasar dan Murni di tingkat SD sudah baik karena telah melebihi angka 90\%, sedangkan untuk tingkat SMP kecamatan Cibeber memang masih rendah.

Berdasarkan Peraturan Pemerintah RI nomor 47 Pasal 3 ayat 1 menyebutkan bahwa wajib belajar dilaksanakan tidak hanya pada jalur pendidikan formal, namun juga nonformal dan informal. Pada ayat tiga dijelaskan bahwa penyelenggaraan wajib belajar pada jalur pendidikan nonformal sendiri adalah melalui progrm paket $A$ dan paket $B$. 
Peranan masyarakat khususnya tokoh masyarakat baik itu memang yang berlatar belakang pendidikan maupun bukan dalam pengawasan pelaksanaan wajib belajar 9 tahun ini lebih berfokus pada pemberian himbauan dan persuasif untuk melaksanakan pendidikan sampai tingkat SMP. Sebagaimana yang tertuang dalam Peraturan Pemerintah nomor 47 tahun 2008 pasal 13 mengenai kewajiban masyarakat dimana masyarakat berkewajiban untuk mendukung penyelenggaraan program wajib belajar. Adapun bentuk dukungan yang dilaksanakan oleh tokoh masyarakat dalam penyelenggaraan program wajib belajar ini lebih kepada dukungan dalam bentuk himbauan dan persuasif.

Heryanto (1998, hlm. Iv) menjelaskan mengenai partisipasi orangtua yang cukup besar dalam pelaksanaan wajib belajar 9 tahun. Terdapat hubungan nyata antara motivasi dengan partisipasi menyekolahkan ke SLTP, dimana semakin tinggi dorongan pada dirinya untuk kemajuan pendidikan anaknya maka semakin tinggi partisipasi menyekolahkan pada jenjang SLTP.

Bentuk interaksi sosial terdapat proses imitasi, sebagaimana yang disampaikan oleh Supardan (2008, hlm. 29) yang mana proses ini merupakan suatu peniruan terhadap suatu kaidah atau nilai-nilai tertentu yang ada di masyarakat. Anak dapat melakukan proses imitasi terhadap apa yang ada di lingkungannya, seperti halnya di wilayah kecamatan Cibeber masih ada anak yang tidak bersekolah yang diakibatkan pengaruh dari pergaulannya dengan anak yang tidak sekolah.

Berdasarkan pengertian nilai budaya menurut Koentjaraningrat (1990, hlm. 190) yaitu sesuatu yang dianggap bernilai, berharga dan penting dalam hidup dan dijadikan sebagai pedoman dalam memberikan arah hidup masyarakat.

Selain itu juga terdapat nilai yang beranggapan bahwa pendidikan pesantren lebih baik daripada pendidikan formal, sehingga masyarakat banyak yang memilih untuk memasukkan anaknya ke pesantren. Hal ini berkaitan pula dengan pandangan pendidikan bagi anak perempuan, dimana anak perempuan lebih banyak yang dimasukkan ke pesantren ataupun dinikahkan daripada melanjutkan sekolah.

\section{PENUTUP}

Pelaksanaan wajib belajar pendidikan dasar 9 tahun yang 
ada di kecamatan Cibeber ini secara umum belum adanya pemerataan. Tokoh masyarakat ini memiliki peran melakukan pengawasan dalam pelaksanaan wajib belajar pendidikan dasar 9 tahun.

Pengawasan yang dilakukan oleh tokoh masyarakat yakni dengan melakukan himbauan kepada masyarakat untuk turut serta menyukseskan pelaksanaan wajib belajar pendidikan 9 tahun. Selain melakukan pengawasan, tokoh masyarakat juga mendukung pelaksanaan wajib belajar 9 tahun dengan jalan:

a. melakukan sosialisasi wajib belajar kepada masyarakat,

b. melakukan pendekatan kepada orangtua siswa agar bersedia untuk menyekolahkan anaknya hingga tingkat SMP,

c. memberikan pemahaman akan pentingnya pendidikan dan juga

d. berperan aktif dalam tim wajar dikdas tingkat kecamatan, desa, RW maupun RT.

Faktor sosial yang mempengaruhi pelaksanaan wajib belajar pendidikan diantaranya adalah interaksi sosial, mobilitas sosial dan stratifikasi sosial.

Terdapat proses peniruan terhadap lingkungan sekitarnya yang dilakukan oleh anak. Anak mengikuti lingkungannya yang terdiri dari anak-anak yang tidak sekolah.

\section{DAFTAR RUJUKAN}

Aulia, S. (2012). Desentralisasi Kebijakan Pendidikan (Studi Tentang Pelaksanaan Wajib Belajar 12 Tahun di Kota Surabaya pada Tingkat Pendidikan Menengah dan Kejuruan). 1 (2), hlm. 204216

Heryanto, N. (1998). Partisipasi Orangtua dalam Program Wajib Belajar Pendidikan Dasar 9 Tahun (Kasus di Kabupaten Garut Provinsi Jawa Barat). (Tesis). Program Pascasarjana, Institut Pertanian Bogor, Bogor. 